\title{
Immunological relevance of the coevolution of IDO1 and AHR
}

\section{Merja Jaronen and Francisco J. Quintana*}

Center for Neurologic Diseases, Brigham and Women's Hospital, Harvard Medical School, Boston, MA, USA

\section{Edited by:}

Ursula Grohmann, University of

Perugia, Italy

\section{Reviewed by:}

Ursula Grohmann, University of

Perugia, Italy

Francesca Fallarino, University of

Perugia, Italy

Michael Platten, German Cancer

Research Center, Germany

*Correspondence:

Francisco J. Quintana, Center for Neurologic Diseases, Brigham and

Women's Hospital, Harvard Medical

School, Boston, MA 02115, USA

e-mail: fquintana@rics.bwh.

harvard.edu

\begin{abstract}
The aryl hydrocarbon receptor (AHR) is a ligand-activated transcription factor initially identified because of its role in controlling the cellular response to environmental molecules. More recently, AHR has been shown to play a crucial role in controlling innate and adaptive immune responses through several mechanisms, one of which is the regulation of tryptophan metabolism. Indoleamine-2,3-dioxygenase (IDO) and tryptophan-2,3-dioxygenase (TDO) are considered rate-limiting enzymes in the tryptophan catabolism and play important roles in the regulation of the immunity. Moreover, AHR and IDO/TDO are closely interconnected: AHR regulates IDO and TDO expression, and kynurenine produced by IDO/TDO is an AHR agonist. In this review, we propose to examine the relationship between AHR and IDO/TDO and its relevance for the regulation of the immune response in health and disease.
\end{abstract}

Keywords: aryl hydrocarbon receptor, 2,3-dioxygenase, tryptophan-2,3-dioxygenase

\section{AHR SIGNALING PATHWAYS}

Aryl hydrocarbon receptor belongs to the family of basic-helixloop-helix/Per-Arnt-Sim transcription factors. It is abundantly expressed in numerous tissues, such as liver, lung, and placenta $(1,2)$. Interestingly, AHR is highly conserved through evolution (3), highlighting its importance across the animal kingdom. Originally, AHR was studied in the context of the biological response to environmental toxins such as 2,3,7,8-tetrachlorodibenzo- $p$-dioxin (TCDD). However, it was later found that AHR has an important role in the regulation of immune responses by small molecules provided by the diet, the commensal flora, and metabolism. In its inactive state, AHR resides in the cytosol as part of a complex that includes other proteins such as the $90 \mathrm{kDa}$ heat shock protein (HSP90), the AHR-interacting protein, $\mathrm{p} 23$, and the c-SRC protein kinase (4-7). It is thought that HSP 90 and p 23 protect the receptor from proteolysis and maintain a conformation suitable for ligand binding (8).

Aryl hydrocarbon receptor is activated by ligands binding the PAS-B domain (9), triggering a conformational change that results in the dissociation of AHR from the chaperone proteins and the exposure of its nuclear localization sequence (10). Ligand activation of AHR elicits genomic and non-genomic AHR-dependent signaling pathways. Genomic AHR signaling involves the interaction of AHR with other transcription factors and co-activators to directly regulate the transcription of target genes (7). After ligand activation, AHR translocates to the nucleus where it dimerizes with the AHR nuclear translocator (ARNT) (11) to form an active DNA-binding complex and control the expression of target genes containing xenobiotic response elements (XREs) in their regulatory regions (9). The AHR-ARNT complex can promote or inhibit the expression of its target genes. Moreover, ChIP-seq and microarray studies with different cell types and ligands (12-14) suggest that the AHR target genes in a specific cell are determined by the ligands, and also the identity and developmental stage of the target cells (15).

Non-genomic AHR signaling is more diverse and encompasses, for example, the release of c-SRC from its complex with AHR, resulting in the phosphorylation of c-SRC cellular targets (7). In addition, AHR can promote the degradation of specific target proteins such as estrogen and androgen receptors by the proteasome. This ability to trigger the degradation of specific proteins results from its E3 ligase activity, by which AHR selects proteins for ubiquitination by E2 ubiquitin-conjugating enzymes. The resulting ubiquitinated proteins are then recognized by the $26 \mathrm{~S}$ proteasome and degraded (16-18). Indeed, following activation AHR itself is eventually exported out from the nucleus and degraded by the $26 \mathrm{~S}$ proteasome pathway (19-21).

Structure-activity relationship studies showed that AHR's ligand binding pocket is promiscuous and able to accommodate numerous hydrophobic planar compounds (22). From an historic point of view, AHR can be seen as an endocrine-disrupting chemicals (EDCs) receptor, as it is known that EDCs affect the endocrine system either directly by AHR-dependent changes in gene expression or indirectly via AHR cross-talk with endocrine signaling pathways (23). However, both endogenous and exogenous AHR ligands have been identified. Classical AHR ligands include synthetic aromatic and polycyclic aromatic hydrocarbons (HAHs and PAHs) as well as natural ligands tetrapyrroles, flavonoids, tryptophan derivatives, and dietary carotinoids (24). Interestingly, some of the natural AHR ligands, such as resveratrol (25) and 7-ketocholestrol (26) can act as antagonists rather than agonists. Within the endogenous AHR ligands, tryptophanderived metabolites have become one of the most interesting and utmost studied group (7). It should be noted that AHR activation 
in the absence of ligand binding has also been described. Although the relevance of this observation for vertebrates is not completely understood, the ligand-independent activation of AHR might play a physiological role in invertebrates (see below).

\section{AHR EVOLUTION}

Aryl hydrocarbon receptor homologs have been identified in most major groups of animals, including the two main clades of protostome invertebrates as well as deuterostomes $(27,28)$ highlighting the biological importance of AHR throughout the animal kingdom. AHR homologs identified in invertebrates share similarities with their vertebrate counterparts, such as the interaction with ARNT to recognize XRE (29-31). However, invertebrate AHR homologs do not bind known AHR ligands like TCDD or $\beta$ naphthoflavone $(29,31)$. Indeed, it was recently reported that the metabolic response to xenobiotics in Caenorhabditis elegans is not controlled by AHR (32).

In C. elegans, the orthologs of AHR and ARNT are encoded by the AHR-related ( $a h r-1)$ and $a h r-1$ associated (aha-1) genes, respectively. AHR-1 and AHA have HSP90 binding properties comparable to those of their mammalian counterparts (31). AHR1 shares 38\% amino acid identity with the human AHR over the first 395 amino acids. Furthermore, AHR-1 contains a PAS domain with both PAS-A and PAS-B repeats as well as a bHLH domain where specific residues mediating the recognition of mammalian XREs are conserved (31). However, AHR-1 does not have a glutamine-rich transcriptional activation domain similar to the one present in mammals.

Notably, mutations in AHR-1 affect several aspects of neuronal development determining, for example, the fate of GABAergic neurons in the L1 larval stage, regulating both cell and axon migrations as well as specifying the fate of AVM light touch sensory neuron (33-35). In addition, AHR-1 is involved in social feeding (36), in which nematodes form groups on the border of the bacterial lawn (37).

Recent studies have also demonstrated a role for AHR-1 in regulating the synthesis of long-chain unsaturated fatty acids that eventually produce lipid signaling molecules (38). This finding is consistent with findings in mouse models, where ligand activation of AHR has been linked to alterations in gene expression of fatty acid metabolism $(39,40)$.

The homologs of mammalian AHR and ARNT are encoded by spineless and tango in Drosophila melanogaster $(41,42)$. In agreement with observations made in $C$. elegans, spineless does not bind TCDD or $\beta$-naphthoflavone (29). In addition, sequence alignments suggest that key residues required for the interaction of mammalian AHR with TCDD are not conserved in spineless $(29,41)$. Thus, although it is still possible that the localization and/or the activity of spineless are modified by unknown endogenous ligands, it appears that this protein does not bind classical AHR ligands functional in mammalian systems. Moreover, in certain cells spineless appears to be constitutively active (43). Spineless plays a role in several aspects of antenna and leg development (41, 44 ), photoreceptor cell differentiation (45), and in controlling the morphology of sensory neurons (46).

Not surprisingly, most of our knowledge on mammalian AHR comes from studies on human beings and mice. Key features characterizing mammalian AHR are (1) in contrast to other vertebrates (47) all studied mammalians have a single AHR gene and (2) AHR in mammals is not only involved in the toxic effects of environmental pollutants $(48,49)$, it also has important roles in development (50-53) and immune responses [reviewed in Ref. (7)]. Indeed, it has been hypothesized that the original function of the AHR might have been developmental regulation and that AHR's ability to bind HAHs, PAHs, and mediate adaptive responses involving induction of xenobiotic-metabolizing enzymes is a vertebrate innovation $(3,47)$.

\section{KYNURENINE PATHWAYS TDO/IDO AND IMMUNE REGULATION}

Tryptophan metabolites have become one of the most interesting groups of endogenous AHR ligands. Especially kynurenine, an immediate tryptophan metabolite, has been extensively studied in recent years. The metabolic fate of tryptophan is conversion into a range of neuroactive substances, such as serotonin and melatonin. In addition, tryptophan can be catabolized into kynurenine metabolites. Indoleamine-2,3-dioxygenase (IDO1), tryptophan2,3-dioxygenase (TDO), and recently discovered IDO-related enzyme IDO2 (54) are the first and rate-limiting enzymes converting tryptophan to $N$-formylkynurenine $(55,56)$ which is then metabolized to L-kynurenine. Both TDO and IDO1 are thought to be intracellular enzymes $(57,58)$. Therefore, ATP-binding cassette (ABC) transporter (59), enzyme facilitating cellular entry of tryptophan, is considered to be another rate-limiting factor in tryptophan catabolism (60). L-Kynurenine can be catabolized by three different ways: (1) kynurenine monooxygenase, kynureninase, and 3-hydroxyanthranilic acid oxidase catalyze the synthesis of anthranilic acid, 3-hydroxyanthranilic acid, quinolinic acid, and 3-hydroxykynurenine. (2) Kynurenine aminotransfereases catalyze the synthesis of kynurenic acid. (3) Kynurenine monooxygenase and kynurenine aminotransfereases catalyze the synthesis of xanthurenic acid (Figure 1) [reviewed in Ref. (61)].

In human beings, IDO1 is expressed in various tissues and cell subsets following cytokine stimulation during infection, transplantation, pregnancy, autoimmunity, and neoplasia (62-64). IDO1 is constitutively expressed in many human tumors, creating an immunosuppressive microenvironment as a result of tryptophan depletion and the synthesis of immunosuppressive metabolites such as kynurenine $(65,66)$. Surprisingly, the expression of IDO1 is controlled by AHR (67) via an autocrine AHR-IL6-STAT3 signaling loop (68). In addition, tryptophan starvation caused by IDO1 activity, together with IDO1-dependent tryptophan catabolism, inhibits the proliferation and activation of antigen-specific $\mathrm{T}$ lymphocytes and induces immune tolerance (69-72). In addition, strong evidence suggests that tryptophan catabolism can inhibit T-cell based adaptive immunity by inducing the differentiation of regulatory $\mathrm{T}$ cells (Treg) in tumors $(62,73-75)$. Interestingly, kynurenine is also indicated to promote the differentiation of Tregs (76) while suppressing antigen-specific T-cell responses (77).

In mammals, TDO2 is expressed primarily in the liver (78-80) but can also be detected in other tissues such as the brain $(79,81-$ $83)$. TDO2 is constitutively expressed and activated in gliomas (84). Recently, lipopolysaccharide was demonstrated to induce TDO2 expression and via consequent production of kynurenine 


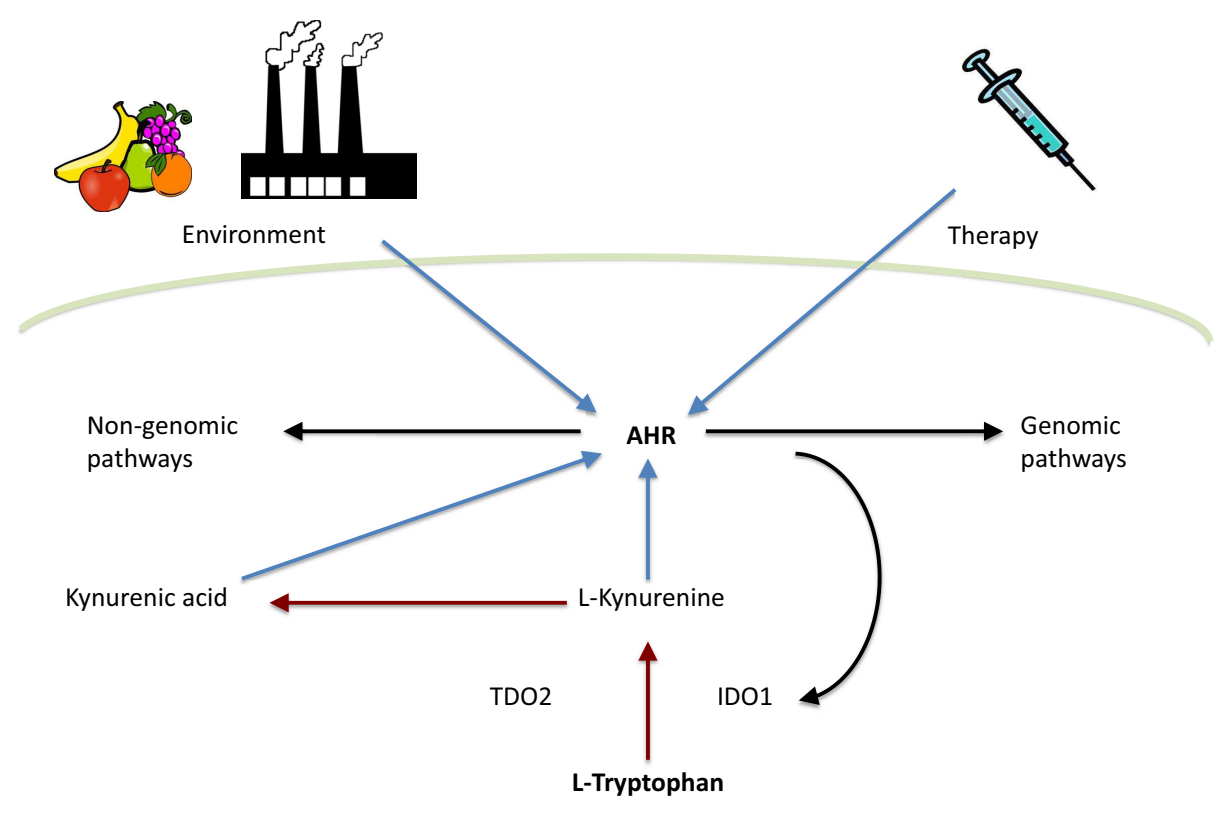

FIGURE 1 | Interplay between tryptophan metabolism and AHR.

Tryptophan is metabolized by TDO2 and IDO1 to L-kynurenine, which is further converted to kynurenic acid. Both L-kynurenine and kynurenic acid can

activate AHR. In addition, AHR activity is influenced by environment and therapy. Finally, AHR can activate either genomic or non-genomic AHR-dependent signaling pathways. Red arrows indicate tryptophan catabolism pathways, blue arrows indicate AHR activation, and black arrows indicate pathways activated by AHR. activate AHR-dependent pathways leading to protection against endotoxin challenge (85). In addition, this study also reported that endotoxin tolerance is also mediated by AHR as it was demonstrated that AHR activation by kynurenine elicits the c-SRC dependent phosphorylation of IDO1, which further regulates TGF $\beta 1$ production by dendritic cells as well as limits immunopathology triggered by both Salmonella typhimurium and group B Streptococcus (85). Furthermore, TDO2 derived kynurenine has been demonstrated to suppress antitumor immune responses as well as promote survival and motility of tumor cells via AHR in an autocrine manner (84). Note that kynurenic acid can also activate AHR signaling (86).

\section{IDO/TDO EVOLUTION}

Unfortunately, not much is know about the kynurenine pathway in nematodes. However, the study of intestinal autofluorescence in relation to tryptophan catabolism revealed that nematodes having a mutated flu-1 gene show altered gut granule autofluoresence as well as decreased kynurenine hydroxylase activity (87). Whereas, flu-2 mutants have reduced kynureninase and gut granule autofluorescence (87). In support of these observations, the C. elegans genome has homologs of kynurenine hydroxylase and kynureninase in the vicinity of $f l u-1$ and $f l u-2$ loci (88).

Additional putative kynurenine pathway related genes have been identified in the C. elegans genome (89) (Figure 2). The knock down of $t d o-2$, for example, abrogated the gut granule fluorescence $(90,91)$. Involvement of the C. elegans kynurenine pathway has been demonstrated in neurodegeneration and aging: in a C. elegans model of Parkinson's disease; RNAi knock down of $t d o-2$ reduced $\alpha$-synuclein aggregation-induced toxicity and

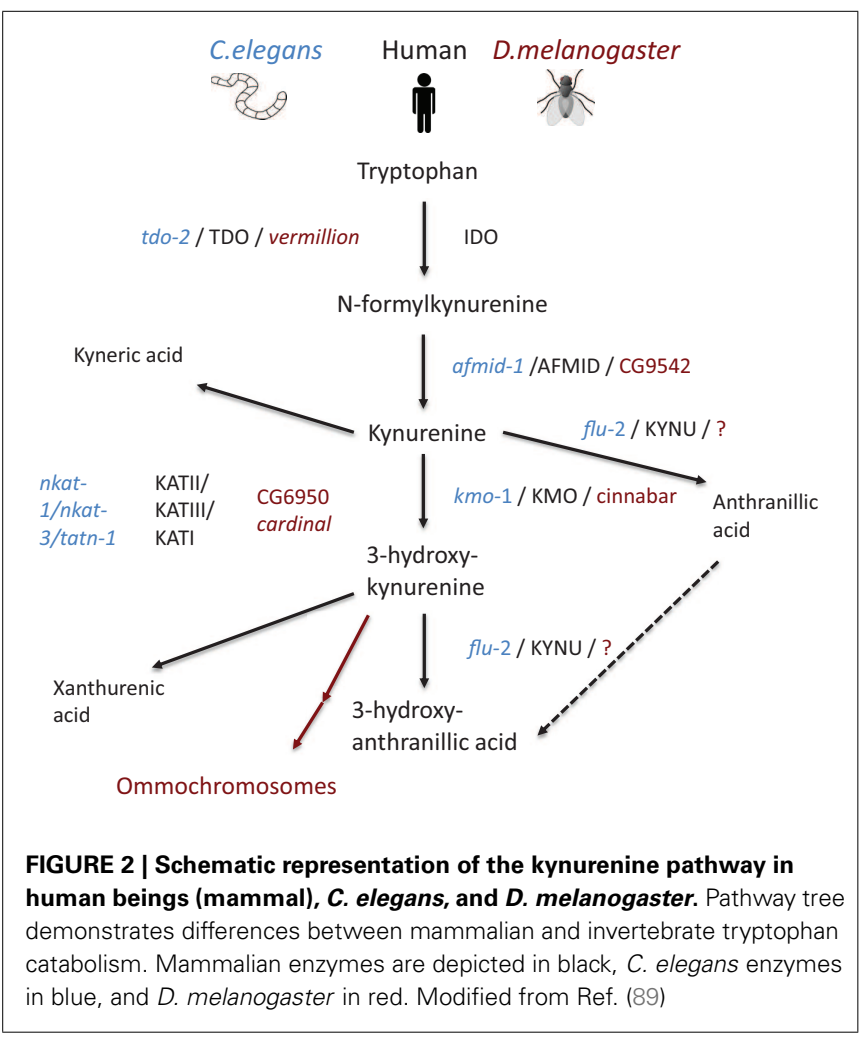

increased life span (92). However, these effects were proven to be a result of increased tryptophan rather than changed levels of kynurenines (92). 
In D. melanogaster, tryptophan catabolism takes place in pigmented eyes (93-95). Remarkably, the role of kynurenine pathway in eye function is conserved from flies to mammals, as it plays an essential role in protecting the lens from ultraviolet irradiation (96). D. melanogaster TDO2 is encoded by vermillion. Flies having the vermillion mutation lack brown pigment in their eyes and have been thought to be deficient for TDO2 activity (93, 94, 97, 98). This was verified when kynurenine pathway and related genes were described in full in 2003 (99). In the same way, as in $C$. elegans, loss of vermillion function has been demonstrated to be neuroprotective in D. melanogaster model of Huntington's disease (100). In addition, loss of vermillion function extend the life span of D. melanogaster $(101,102)$ while resulting gradual memory decline (103). Furthermore, white eye mutants having impaired ABC transport show extended life spans (102). In addition, other D. melanogaster mutants, cardinal and cinnabar, resulting in excess of 3-hydroxykynurenine and neuroprotective kynurenic acid, have been demonstrated to modify the brain plasticity (104).

\section{CONCLUSION}

Aryl hydrocarbon receptor, a member of the dHLH-PAS superfamily, has been identified both in invertebrates and vertebrates, suggesting that the ancestral AHR gene arose over 500 million years ago (3). In vertebrates, especially in mammals, the activity of AHR is mostly regulated by its interactions with ligands. However, in invertebrates (e.g. C. elegans) AHR does not seem to interact with TCDD or any other known ligand (105), and it is constitutively localized in the nuclei of certain cells suggesting ligand-independent activation (34). Similar observations have been made for D. melanogaster's spineless (29). Although one cannot rule out the possibility that invertebrates require a different kind of AHR ligands than vertebrates, it has been speculated that in early metazoans AHR might have had a ligand-independent roles in development. Thus, the ability of AHR to interact with ligands, bind HAHs and PAHs, and regulate xenobiotic-metabolizing enzymes has been postulated to be a vertebrate novelty $(3,47)$.

Aryl hydrocarbon receptor signaling modulates development and immune function in mammals (7). Fairly recently, the involvement of tryptophan metabolism has been implicated in regulating both innate and adaptive immune responses. Most importantly, kynurenine produced by TDO or IDO1 during tryptophan catabolism has been identified as an AHR ligand, linking IDO/TDO to AHR. Considering the evolutionary conservation of the kynurenine pathway, it is tempting to speculate that the cross-talk between AHR and IDO/TDO immunoregulatory pathways is a recent evolutionary innovation aimed at providing a mechanism to fine tune the immune response in response to environmental cues provided by the tissue microenvironment. This interpretation suggests that approaches targeting both AHR and IDO/TDO are likely to provide efficient new avenues for the therapeutic manipulation of the immune response.

\section{ACKNOWLEDGMENTS}

This project has been supported by the National Multiple Sclerosis Society, the National Institutes of Health, the Sigrid Juselius Foundation, the Paulo Foundation, and the Finnish Multiple Sclerosis Foundation.

\section{REFERENCES}

1. Dolwick KM, Schmidt JV, Carver LA, Swanson HI, Bradfield CA. Cloning and expression of a human Ah receptor cDNA. Mol Pharmacol (1993) 44:911-7.

2. Dolwick KM, Swanson HI, Bradfield CA. In vitro analysis of Ah receptor domains involved in ligand-activated DNA recognition. Proc Natl Acad Sci U S A (1993) 90:8566-70. doi:10.1073/pnas.90.18.8566

3. Hahn ME. Aryl hydrocarbon receptors: diversity and evolution. Chem Biol Interact (2002) 141:131-60. doi:10.1016/S0009-2797(02)00070-4

4. Kazlauskas A, Poellinger L, Pongratz I. Evidence that the co-chaperone p23 regulates ligand responsiveness of the dioxin (Aryl hydrocarbon) receptor. J Biol Chem (1999) 274:13519-24. doi:10.1074/jbc.274.19.13519

5. Ma Q, Whitlock JP Jr. A novel cytoplasmic protein that interacts with the Ah receptor, contains tetratricopeptide repeat motifs, and augments the transcriptional response to 2,3,7,8-tetrachlorodibenzo-p-dioxin. J Biol Chem (1997) 272:8878-84. doi:10.1074/jbc.272.14.8878

6. Perdew GH. Association of the Ah receptor with the $90-\mathrm{kDa}$ heat shock protein. J Biol Chem (1988) 263:13802-5.

7. Quintana FJ, Sherr DH. Aryl hydrocarbon receptor control of adaptive immunity. Pharmacol Rev (2013) 65:1148-61. doi:10.1124/pr.113.007823

8. Cox MB, Miller CA III. Cooperation of heat shock protein 90 and p23 in aryl hydrocarbon receptor signaling. Cell Stress Chaperones (2004) 9:4-20. doi:10.1379/460.1

9. Fukunaga BN, Probst MR, Reisz-Porszasz S, Hankinson O. Identification of functional domains of the aryl hydrocarbon receptor. J Biol Chem (1995) 270:29270-8. doi:10.1074/jbc.270.49.29270

10. Ikuta T, Kobayashi Y, Kawajiri K. Phosphorylation of nuclear localization signal inhibits the ligand-dependent nuclear import of aryl hydrocarbon receptor. Biochem Biophys Res Commun (2004) 317:545-50. doi:10.1016/j.bbrc.2004. 03.076

11. Reyes H, Reisz-Porszasz S, Hankinson O. Identification of the Ah receptor nuclear translocator protein (Arnt) as a component of the DNA binding form of the Ah receptor. Science (1992) 256:1193-5. doi:10.1126/science.256. 5060.1193

12. Adachi J, Mori Y, Matsui S, Matsuda T. Comparison of gene expression patterns between 2,3,7,8-tetrachlorodibenzo-p-dioxin and a natural arylhydrocarbon receptor ligand, indirubin. Toxicol Sci (2004) 80:161-9. doi:10.1093/ toxsci/kfh 129

13. Hao N, Lee KL, Furness SGB, Bosdotter C, Poellinger L, Whitelaw ML. Xenobiotics and loss of cell adhesion drive distinct transcriptional outcomes by aryl hydrocarbon receptor signaling. Mol Pharmacol (2012) 82:1082-93. doi:10.1124/mol.112.078873

14. Lo R, Matthews J. High-resolution genome-wide mapping of AHR and ARNT binding sites by ChIP-Seq. Toxicol Sci (2012) 130:349-61. doi:10.1093/toxsci/ $\mathrm{kfs} 253$

15. Murray IA, Morales JL, Flaveny CA, Dinatale BC, Chiaro C, Gowdahalli K, et al. Evidence for ligand-mediated selective modulation of aryl hydrocarbon receptor activity. Mol Pharmacol (2010) 77:247-54. doi:10.1124/mol.109.061788

16. Ohtake F, Fujii-Kuriyama Y, Kato S. AHR acts as an E3 ubiquitin ligase to modulate steroid receptor functions. Biochem Pharmacol (2009) 77:474-84. doi:10.1016/j.bcp.2008.08.034

17. Ohtake F, Baba A, Fujii-Kuriyama Y, Kato S. Intrinsic AHR function underlies cross-talk of dioxins with sex hormone signalings. Biochem Biophys Res Commun (2008) 370:541-6. doi:10.1016/j.bbrc.2008.03.054

18. Ohtake F, Baba A, Takada I, Okada M, Iwasaki K, Miki H, et al. Dioxin receptor is a ligand-dependent E3 ubiquitin ligase. Nature (2007) 446:562-6. doi:10.1038/nature05683

19. Davarinos NA, Pollenz RS. Aryl hydrocarbon receptor imported into the nucleus following ligand binding is rapidly degraded via the cytosplasmic proteasome following nuclear export. J Biol Chem (1999) 274:28708-15. doi:10.1074/jbc.274.40.28708

20. Ma Q, Baldwin KT. 2,3,7,8-tetrachlorodibenzo-p-dioxin-induced degradation of aryl hydrocarbon receptor (AHR) by the ubiquitin-proteasome pathway. Role of the transcription activaton and DNA binding of AHR. J Biol Chem (2000) 275:8432-8. doi:10.1074/jbc.275.12.8432

21. Pollenz RS, Barbour ER. Analysis of the complex relationship between nuclear export and aryl hydrocarbon receptor-mediated gene regulation. Mol Cell Biol (2000) 20:6095-104. doi:10.1128/MCB.20.16.6095-6104.2000

22. Waller CL, McKinney JD. Three-dimensional quantitative structure-activity relationships of dioxins and dioxin-like compounds: model validation and 
Ah receptor characterization. Chem Res Toxicol (1995) 8:847-58. doi:10.1021/ tx00048a005

23. Carlson DB, Perdew GH. A dynamic role for the Ah receptor in cell signaling? Insights from a diverse group of Ah receptor interacting proteins. J Biochem Mol Toxicol (2002) 16:317-25. doi:10.1002/jbt.10051

24. Denison MS, Nagy SR. Activation of the aryl hydrocarbon receptor by structurally diverse exogenous and endogenous chemicals. Annu Rev Pharmacol Toxicol (2003) 43:309-34. doi:10.1146/annurev.pharmtox.43.100901.135828

25. Casper RF, Quesne M, Rogers IM, Shirota T, Jolivet A, Milgrom E, et al. Resveratrol has antagonist activity on the aryl hydrocarbon receptor: implications for prevention of dioxin toxicity. Mol Pharmacol (1999) 56:784-90.

26. Savouret JF, Antenos M, Quesne M, Xu J, Milgrom E, Casper RF. 7ketocholesterol is an endogenous modulator for the arylhydrocarbon receptor. J Biol Chem (2001) 276:3054-9. doi:10.1074/jbc.M005988200

27. Peterson KJ, Butterfield NJ. Origin of the Eumetazoa: testing ecological predictions of molecular clocks against the Proterozoic fossil record. Proc Natl Acad Sci US A (2005) 102:9547-52. doi:10.1073/pnas.0503660102

28. Peterson KJ, Lyons JB, Nowak KS, Takacs CM, Wargo MJ, McPeek MA. Estimating metazoan divergence times with a molecular clock. Proc Natl Acad Sci U S A (2004) 101:6536-41. doi:10.1073/pnas.0401670101

29. Butler RA, Kelley ML, Powell WH, Hahn ME, Van Beneden RJ. An aryl hydrocarbon receptor (AHR) homologue from the soft-shell clam, Mya arenaria: evidence that invertebrate AHR homologues lack 2,3,7,8-tetrachlorodibenzop-dioxin and beta-naphthoflavone binding. Gene (2001) 278:223-34. doi:10. 1016/S0378-1119(01)00724-7

30. Emmons RB, Duncan D, Estes PA, Kiefel P, Mosher JT, Sonnenfeld M, et al. The spineless-aristapedia and tango bHLH-PAS proteins interact to control antennal and tarsal development in Drosophila. Development (1999) 126:3937-45.

31. Powell-Coffman JA, Bradfield CA, Wood WB. Caenorhabditis elegans orthologs of the aryl hydrocarbon receptor and its heterodimerization partner the aryl hydrocarbon receptor nuclear translocator. Proc Natl Acad Sci U S A (1998) 95:2844-9. doi:10.1073/pnas.95.6.2844

32. Jones LM, Rayson SJ, Flemming AJ, Urwin PE. Adaptive and specialised transcriptional responses to xenobiotic stress in Caenorhabditis elegans are regulated by nuclear hormone receptors. PLoS One (2013) 8:e69956. doi:10.1371/ journal.pone.0069956

33. Huang X, Powell-Coffman JA, Jin Y. The AHR-1 aryl hydrocarbon receptor and its co-factor the AHA-1 aryl hydrocarbon receptor nuclear translocator specify GABAergic neuron cell fate in C. elegans. Development (2004) 131:819-28. doi:10.1242/dev.00959

34. Qin H, Powell-Coffman JA. The Caenorhabditis elegans aryl hydrocarbon receptor, AHR-1, regulates neuronal development. Dev Biol (2004) 270:64-75. doi:10.1016/j.ydbio.2004.02.004

35. Smith CJ, O’Brien T, Chatzigeorgiou M, Spencer WC, Feingold-Link E, Husson SJ, et al. Sensory neuron fates are distinguished by a transcriptional switch that regulates dendrite branch stabilization. Neuron (2013) 79:266-80. doi:10.1016/j.neuron.2013.05.009

36. Qin H, Zhai Z, Powell-Coffman JA. The Caenorhabditis elegans AHR-1 transcription complex controls expression of soluble guanylate cyclase genes in the URX neurons and regulates aggregation behavior. Dev Biol (2006) 298:606-15. doi:10.1016/j.ydbio.2006.07.017

37. de Bono M, Bargmann CI. Natural variation in a neuropeptide Y receptor homolog modifies social behavior and food response in C. elegans. Cell (1998) 94:679-89. doi:10.1016/S0092-8674(00)81609-8

38. Aarnio V, Storvik M, Lehtonen M, Asikainen S, Reisner K, Callaway J, et al. Fatty acid composition and gene expression profiles are altered in aryl hydrocarbon receptor-1 mutant Caenorhabditis elegans. Comp Biochem Physiol C Toxicol Pharmacol (2010) 151:318-24. doi:10.1016/j.cbpc.2009.12.006

39. Boverhof DR, Burgoon LD, Tashiro C, Chittim B, Harkema JR, Jump DB, et al. Temporal and dose-dependent hepatic gene expression patterns in mice provide new insights into TCDD-Mediated hepatotoxicity. Toxicol Sci (2005) 85:1048-63. doi:10.1093/toxsci/kfil62

40. Sato S, Shirakawa H, Tomita S, Ohsaki Y, Haketa K, Tooi O, et al. Lowdose dioxins alter gene expression related to cholesterol biosynthesis, lipogenesis, and glucose metabolism through the aryl hydrocarbon receptormediated pathway in mouse liver. Toxicol Appl Pharmacol (2008) 229:10-9. doi:10.1016/j.taap.2007.12.029
41. Duncan DM, Burgess EA, Duncan I. Control of distal antennal identity and tarsal development in Drosophila by spineless-aristapedia, a homolog of the mammalian dioxin receptor. Genes Dev (1998) 12:1290-303. doi:10.1101/gad. 12.9.1290

42. Sonnenfeld M, Ward M, Nystrom G, Mosher J, Stahl S, Crews S. The Drosophila tango gene encodes a bHLH-PAS protein that is orthologous to mammalian Arnt and controls CNS midline and tracheal development. Development (1997) 124:4571-82.

43. Kudo K, Takeuchi T, Murakami Y, Ebina M, Kikuchi H. Characterization of the region of the aryl hydrocarbon receptor required for ligand dependency of transactivation using chimeric receptor between Drosophila and Mus musculus. Biochim Biophys Acta (2009) 1789:477-86. doi:10.1016/j.bbagrm. 2009.06.003

44. Struhl G. Spineless-aristapedia: a homeotic gene that does not control the development of specific compartments in Drosophila. Genetics (1982) 102:737-49.

45. Wernet MF, Mazzoni EO, Celik A, Duncan DM, Duncan I, Desplan C. Stochastic spineless expression creates the retinal mosaic for colour vision. Nature (2006) 440:174-80. doi:10.1038/nature04615

46. Kim MD, Jan LY, Jan YN. The bHLH-PAS protein spineless is necessary for the diversification of dendrite morphology of Drosophila dendritic arborization neurons. Genes Dev (2006) 20:2806-19. doi:10.1101/gad.1459706

47. Hahn ME, Karchner SI, Evans BR, Franks DG, Merson RR, Lapseritis JM. Unexpected diversity of aryl hydrocarbon receptors in non-mammalian vertebrates: insights from comparative genomics. J Exp Zoolog A Comp Exp Biol (2006) 305:693-706. doi:10.1002/jez.a.323

48. Fernandez-Salguero PM, Hilbert DM, Rudikoff S, Ward JM, Gonzalez FJ. Aryl-hydrocarbon receptor-deficient mice are resistant to 2,3,7,8tetrachlorodibenzo-p-dioxin-induced toxicity. Toxicol Appl Pharmacol (1996) 140:173-9. doi:10.1006/taap.1996.0210

49. Mimura J, Yamashita K, Nakamura K, Morita M, Takagi TN, Nakao K, et al. Loss of teratogenic response to 2,3,7,8-tetrachlorodibenzo-p-dioxin (TCDD) in mice lacking the Ah (dioxin) receptor. Genes Cells (1997) 2:645-54. doi:10.1046/j.1365-2443.1997.1490345.x

50. Benedict JC, Lin TM, Loeffler IK, Peterson RE, Flaws JA. Physiological role of the aryl hydrocarbon receptor in mouse ovary development. Toxicol Sci (2000) 56:382-8. doi:10.1093/toxsci/56.2.382

51. Lahvis GP, Lindell SL, Thomas RS, McCuskey RS, Murphy C, Glover E, et al. Portosystemic shunting and persistent fetal vascular structures in aryl hydrocarbon receptor-deficient mice. Proc Natl Acad Sci U S A (2000) 97:10442-7. doi:10.1073/pnas.190256997

52. Robles R, Morita Y, Mann KK, Perez GI, Yang S, Matikainen T, et al. The aryl hydrocarbon receptor, a basic helix-loop-helix transcription factor of the PAS gene family, is required for normal ovarian germ cell dynamics in the mouse. Endocrinology (2000) 141:450-3. doi:10.1210/endo.141.1.7374

53. Schmidt JV, Su GH, Reddy JK, Simon MC, Bradfield CA. Characterization of a murine AHR null allele: involvement of the Ah receptor in hepatic growth and development. Proc Natl Acad Sci U S A (1996) 93:6731-6. doi:10.1073/pnas.93.13.6731

54. Ball HJ, Sanchez-Perez A, Weiser S, Austin CJD, Astelbauer F, Miu $\mathrm{J}$, et al. Characterization of an indoleamine 2,3-dioxygenase-like protein found in humans and mice. Gene (2007) 396:203-13. doi:10.1016/j.gene.2007. 04.010

55. Shimizu T, Nomiyama S, Hirata F, Hayaishi O. Indoleamine 2,3-dioxygenase. Purification and some properties. J Biol Chem (1978) 253:4700-6.

56. Takikawa O, Kuroiwa T, Yamazaki F, Kido R. Mechanism of interferongamma action. Characterization of indoleamine 2,3-dioxygenase in cultured human cells induced by interferon-gamma and evaluation of the enzymemediated tryptophan degradation in its anticellular activity. J Biol Chem (1988) 263:2041-8.

57. Kudo Y, Boyd CA, Sargent IL, Redman CW. Tryptophan degradation by human placental indoleamine 2,3-dioxygenase regulates lymphocyte proliferation. J Physiol (2001) 535:207-15. doi:10.1111/j.1469-7793.2001.00207.x

58. Pfefferkorn ER, Rebhun S, Eckel M. Characterization of an indoleamine 2,3dioxygenase induced by gamma-interferon in cultured human fibroblasts. J Interferon Res (1986) 6:267-79. doi:10.1089/jir.1986.6.267

59. Mackenzie SM, Brooker MR, Gill TR, Cox GB, Howells AJ, Ewart GD. Mutations in the white gene of Drosophila melanogaster affecting ABC transporters 
that determine eye colouration. Biochim Biophys Acta (1999) 1419:173-85. doi:10.1016/S0005-2736(99)00064-4

60. Sullivan DT, Bell LA, Paton DR, Sullivan MC. Genetic and functional analysis of tryptophan transport in Malpighian tubules of Drosophila. Biochem Genet (1980) 18:1109-30. doi:10.1007/BF00484342

61. Campbell BM, Charych E, Lee AW, Möller T. Kynurenines in CNS disease: regulation by inflammatory cytokines. Front Neurosci (2014) 8:12. doi:10.3389/fnins.2014.00012

62. Curti A, Trabanelli S, Salvestrini V, Baccarani M, Lemoli RM. The role of indoleamine 2,3-dioxygenase in the induction of immune tolerance: focus on hematology. Blood (2009) 113:2394-401. doi:10.1182/blood-2008-07-144485

63. Liu X, Liu Y, Ding M, Wang X. Reduced expression of indoleamine 2,3dioxygenase participates in pathogenesis of preeclampsia via regulatory $\mathrm{T}$ cells. Mol Med Rep (2011) 4:53-8. doi:10.3892/mmr.2010.395

64. Maby-El Hajjami H, Amé-Thomas P, Pangault C, Tribut O, DeVos J, Jean R, et al. Functional alteration of the lymphoma stromal cell niche by the cytokine context: role of indoleamine-2,3 dioxygenase. Cancer Res (2009) 69:3228-37. doi:10.1158/0008-5472.CAN-08-3000

65. Munn DH, Mellor AL. Indoleamine 2,3-dioxygenase and tumor-induced tolerance. J Clin Invest (2007) 117:1147-54. doi:10.1172/JCI31178

66. Platten M, Wick W, Van den Eynde BJ. Tryptophan catabolism in cancer: beyond IDO and tryptophan depletion. Cancer Res (2012) 72:5435-40. doi:10.1158/0008-5472.CAN-12-0569

67. Vogel CFA, Goth SR, Dong B, Pessah IN, Matsumura F. Aryl hydrocarbon receptor signaling mediates expression of indoleamine 2,3-dioxygenase. Biochem Biophys Res Commun (2008) 375:331-5. doi:10.1016/j.bbrc.2008.07.156

68. Litzenburger UM, Opitz CA, Sahm F, Rauschenbach KJ, Trump S, Winter $\mathrm{M}$, et al. Constitutive IDO expression in human cancer is sustained by an autocrine signaling loop involving IL-6, STAT3 and the AHR. Oncotarget (2014) 5:1038-51.

69. Frumento G, Rotondo R, Tonetti M, Damonte G, Benatti U, Ferrara GB. Tryptophan-derived catabolites are responsible for inhibition of $\mathrm{T}$ and natural killer cell proliferation induced by indoleamine 2,3-dioxygenase. J Exp Med (2002) 196:459-68. doi:10.1084/jem.20020121

70. Grohmann U, Fallarino F, Puccetti P. Tolerance, DCs and tryptophan: much ado about IDO. Trends Immunol (2003) 24:242-8. doi:10.1016/S1471-4906(03) 00072-3

71. Mellor AL, Keskin DB, Johnson T, Chandler P, Munn DH. Cells expressing indoleamine 2,3-dioxygenase inhibit T cell responses. J Immunol (2002) 1950(168):3771-6. doi:10.4049/jimmunol.168.8.3771

72. Sznurkowski JJ, Zawrocki A, Emerich J, Sznurkowska K, Biernat W. Expression of indoleamine 2,3-dioxygenase predicts shorter survival in patients with vulvar squamous cell carcinoma (vSCC) not influencing on the recruitment of FOXP3-expressing regulatory T cells in cancer nests. Gynecol Oncol (2011) 122:307-12. doi:10.1016/j.ygyno.2011.04.050

73. Curti A, Trabanelli S, Onofri C, Aluigi M, Salvestrini V, Ocadlikova $\mathrm{D}$, et al. Indoleamine 2,3-dioxygenase-expressing leukemic dendritic cells impair a leukemia-specific immune response by inducing potent $\mathrm{T}$ regulatory cells. Haematologica (2010) 95:2022-30. doi:10.3324/haematol.2010. 025924

74. Curti A, Pandolfi S, Valzasina B, Aluigi M, Isidori A, Ferri E, et al. Modulation of tryptophan catabolism by human leukemic cells results in the conversion of CD25- into CD25+ T regulatory cells. Blood (2007) 109:2871-7. doi:10.1182/blood-2006-07-036863

75. Levina V, Su Y, Gorelik E. Immunological and nonimmunological effects of indoleamine 2,3-dioxygenase on breast tumor growth and spontaneous metastasis formation. Clin Dev Immunol (2012) 2012:173029. doi:10.1155/2012/ 173029

76. Mezrich JD, Fechner JH, Zhang X, Johnson BP, Burlingham WJ, Bradfield CA. An interaction between kynurenine and the aryl hydrocarbon receptor can generate regulatory T cells. J Immunol (2010) 1950(185):3190-8. doi:10.4049/jimmunol.0903670

77. Platten M, Ho PP, Youssef S, Fontoura P, Garren H, Hur EM, et al. Treatment of autoimmune neuroinflammation with a synthetic tryptophan metabolite. Science (2005) 310:850-5. doi:10.1126/science.1117634

78. Britan A, Maffre V, Tone S, Drevet JR. Quantitative and spatial differences in the expression of tryptophan-metabolizing enzymes in mouse epididymis. Cell Tissue Res (2006) 324:301-10. doi:10.1007/s00441-005-0151-7
79. Haber R, Bessette D, Hulihan-Giblin B, Durcan MJ, Goldman D. Identification of tryptophan 2,3-dioxygenase RNA in rodent brain. J Neurochem (1993) 60:1159-62. doi:10.1111/j.1471-4159.1993.tb03269.x

80. Yuasa HJ, Takubo M, Takahashi A, Hasegawa T, Noma H, Suzuki T. Evolution of vertebrate indoleamine 2,3-dioxygenases. J Mol Evol (2007) 65:705-14 doi:10.1007/s00239-007-9049-1

81. Miller CL, Llenos IC, Dulay JR, Barillo MM, Yolken RH, Weis S. Expression of the kynurenine pathway enzyme tryptophan 2,3-dioxygenase is increased in the frontal cortex of individuals with schizophrenia. Neurobiol Dis (2004) 15:618-29. doi:10.1016/j.nbd.2003.12.015

82. Minatogawa Y, Suzuki S, Ando Y, Tone S, Takikawa O. Tryptophan pyrrole ring cleavage enzymes in placenta. Adv Exp Med Biol (2003) 527:425-34. doi:10.1007/978-1-4615-0135-0_50

83. Suzuki S, Toné S, Takikawa O, Kubo T, Kohno I, Minatogawa Y. Expression of indoleamine 2,3-dioxygenase and tryptophan 2,3-dioxygenase in early concepti. Biochem $J$ (2001) 355:425-9. doi:10.1042/0264-6021: 3550425

84. Opitz CA, Litzenburger UM, Sahm F, Ott M, Tritschler I, Trump S, et al. An endogenous tumour-promoting ligand of the human aryl hydrocarbon receptor. Nature (2011) 478:197-203. doi:10.1038/nature10491

85. Bessede A, Gargaro M, Pallotta MT, Matino D, Servillo G, Brunacci C, et al. Aryl hydrocarbon receptor control of a disease tolerance defence pathway. Nature (2014) 511:184-90. doi:10.1038/nature13323

86. DiNatale BC, Murray IA, Schroeder JC, Flaveny CA, Lahoti TS, Laurenzana EM, et al. Kynurenic acid is a potent endogenous aryl hydrocarbon receptor ligand that synergistically induces interleukin- 6 in the presence of inflammatory signaling. Toxicol Sci (2010) 115:89-97. doi:10.1093/toxsci/ $\mathrm{kfq024}$

87. Siddiqui SS, Babu P. Kynurenine hydroxylase mutants of the nematode Caenorhabditis elegans. Mol Gen Genet (1980) 179:21-4. doi:10.1007/ BF00268441

88. Altschul SF, Gish W, Miller W, Myers EW, Lipman DJ. Basic local alignment search tool. J Mol Biol (1990) 215:403-10. doi:10.1016/S0022-2836(05) 80360-2

89. Van der Goot AT, Nollen EAA. Tryptophan metabolism: entering the field of aging and age-related pathologies. Trends Mol Med (2013) 19:336-44. doi:10.1016/j.molmed.2013.02.007

90. Coburn C, Allman E, Mahanti P, Benedetto A, Cabreiro F, Pincus Z, et al. Anthranilate fluorescence marks a calcium-propagated necrotic wave that promotes organismal death in C. elegans. PLoS Biol (2013) 11:e1001613. doi:10.1371/journal.pbio.1001613

91. Coburn C, Gems D. The mysterious case of the C. elegans gut granule: death fluorescence, anthranilic acid and the kynurenine pathway. Front Genet (2013) 4:151. doi:10.3389/fgene.2013.00151

92. Van der Goot AT, Zhu W, Vázquez-Manrique RP, Seinstra RI, Dettmer K, Michels $\mathrm{H}$, et al. Delaying aging and the aging-associated decline in protein homeostasis by inhibition of tryptophan degradation. Proc Natl Acad Sci U S A (2012) 109:14912-7. doi:10.1073/pnas.1203083109

93. Baillie DL, Chovnick A. Studies on the genetic control of tryptophan pyrrolase in Drosophila melanogaster. Mol Gen Genet (1971) 112:341-53. doi:10.1007/ BF00334435

94. Tartof KD. Interacting gene systems: I. the regulation of tryptophan pyrrolase by the vermilion-suppressor of vermilion system in Drosophila. Genetics (1969) 62:781-95.

95. Tearle R. Tissue specific effects of ommochrome pathway mutations in Drosophila melanogaster. Genet Res (1991) 57:257-66. doi:10.1017/ S0016672300029402

96. Roberts JE. Ocular phototoxicity. J Photochem Photobiol B (2001) 64:136-43. doi:10.1016/S1011-1344(01)00196-8

97. Beadle GW, Ephrussi B. Development of eye colors in Drosophila: transplantation experiments with suppressor of vermilion. Proc Natl Acad Sci US A (1936) 22:536-40. doi:10.1073/pnas.22.9.536

98. Searles LL, Voelker RA. Molecular characterization of the Drosophila vermilion locus and its suppressible alleles. Proc Natl Acad Sci U S A (1986) 83:404-8. doi:10.1073/pnas.83.2.404

99. Savvateeva-Popova EV, Popov AV, Heinemann T, Riederer P. Drosophila mutants of the kynurenine pathway as a model for ageing studies. Adv Exp Med Biol (2003) 527:713-22. doi:10.1007/978-1-4615-0135-0_84 
100. Campesan S, Green EW, Breda C, Sathyasaikumar KV, Muchowski PJ, Schwarcz $\mathrm{R}$, et al. The kynurenine pathway modulates neurodegeneration in a Drosophila model of Huntington's disease. Curr Biol (2011) 21:961-6. doi:10.1016/j.cub. 2011.04 .028

101. Oxenkrug GF. The extended life span of Drosophila melanogaster eye-color (white and vermilion) mutants with impaired formation of kynurenine. J Neural Transm (2010) 1996(117):23-6. doi:10.1007/s00702-009-0341-7

102. Oxenkrug GF, Navrotskaya V, Voroboyva L, Summergrad P. Extension of life span of Drosophila melanogaster by the inhibitors of tryptophan-kynurenine metabolism. Fly (Austin) (2011) 5:307-9. doi:10.4161/fly.5.4.18414

103. Savvateeva EV, Popov AV, Kamyshev NG, Iliadi KG, Bragina JV, Heisenberg $\mathrm{M}$, et al. Age-dependent changes in memory and mushroom bodies in the Drosophila mutant vermilion deficient in the kynurenine pathway of tryptophan metabolism. Ross Fiziol Zh Im I M Sechenova (1999) 85:167-83.

104. Savvateeva E, Popov A, Kamyshev N, Bragina J, Heisenberg M, Senitz $\mathrm{D}$, et al. Age-dependent memory loss, synaptic pathology and altered brain plasticity in the Drosophila mutant cardinal accumulating 3hydroxykynurenine. J Neural Transm (2000) 1996(107):581-601. doi:10.1007/ s007020070080
105. Powell-Coffman JA, Qin H. Invertebrate AHR homologs: ancestral functions in sensory systems. In: Pohjanvirta R, editor. The AH Receptor in Biology and Toxicology. Hoboken, NJ: John Wiley \& Sons, Inc (2011). p. 405-11.

Conflict of Interest Statement: The authors declare that the research was conducted in the absence of any commercial or financial relationships that could be construed as a potential conflict of interest.

Received: 10 September 2014; accepted: 06 October 2014; published online: 20 October 2014.

Citation: Jaronen $M$ and Quintana FJ (2014) Immunological relevance of the coevolution of IDO1 and AHR. Front. Immunol. 5:521. doi: 10.3389/fimmu.2014.00521

This article was submitted to Immunological Tolerance, a section of the journal Frontiers in Immunology.

Copyright (C) 2014 Jaronen and Quintana. This is an open-access article distributed under the terms of the Creative Commons Attribution License (CC BY). The use, distribution or reproduction in other forums is permitted, provided the original author(s) or licensor are credited and that the original publication in this journal is cited, in accordance with accepted academic practice. No use, distribution or reproduction is permitted which does not comply with these terms. 